\title{
PENGARUH KARAKTERISTIK SOSIAL EKONOMI KELUARGA TERHADAP POLA ASUH BELAJAR SISWA SEKOLAH DASAR DAN MENENGAH PERTAMA
}

\author{
The Effect of Family Socio-economic Characteristics Towards Parenting Pattern of \\ Studying Habits Among Elementary and Secondary High School Students
}

\author{
HERIEN PUSPITAWATI ${ }^{1^{*}}$ \\ ${ }^{1}$ Staf Pengajar Departemen IImu Keluarga dan Konsumen, Fakultas Ekologi Manusia, \\ Institut Pertanian Bogor, Jalan Lingkar Kampus IPB Dramaga, \\ Bogor 16680 serta Tim Pakar Gender Departemen Pendidikan Nasional-RI
}

\begin{abstract}
The main purpose of this research was to know the effect of family socio-economic characteristics towards parenting pattern of studying habits among elementary and secondary high schools. The respondents were parents from elementary and secondary high school. This was a cross sectional study which was performed among 400 parents at District of Indramayu, West Java Province in February-March 2009 who was selected purposively by the school principals. This research used the secondary data from the research investigated by Puspitawati et al. (2009) with title of "Parent Satisfaction Survey of Basic Education Services Provided by Decentralized School System" that was funded by PRMAP-ADB and Bappenas collaborated with $L P P M-I P B$. The results showed that most of respondents facilitated their children's education at home with quite good level of facilities at home. It was shown that parents implemented parenting pattern of studying habits among their children with moderate level of parenting pattern. Based on SEM analysis, it was found that parenting pattern of studying habits performed by parents was influenced directly positive by family social characteristics among elementary students; it was influenced directly and indirectly negative by family social characteristics among secondary high school students; and it was influenced directly positive by family economic characteristics and education facilities at home among all students.
\end{abstract}

Key words: parenting pattern, schools, studying habits

\section{PENDAHULUAN}

Sistem Pendidikan Nasional di Indonesia berdasarkan Pancasila, Undangundang Dasar Republik Indonesia 1945 dan Undang-undang Nomor 20/2003. Fungsi pendidikan nasional adalah untuk membangun kemampuan, karakter dan kepribadian bangsa untuk meningkatkan kapasitas intelektual. Sementara itu, tujuan pendidikan nasional adalah untuk membangun potensial peserta didik sehingga menjadi orang yang berkepribadian tinggi, berakhlak mulia, sehat, berpengetahuan, kompeten, kreatif, merdeka, dan demokratis serta bertanggung jawab (Departemen Pendidikan Nasional 2006).

Kondisi pendidikan di Indonesia saat ini memperlihatkan Angka Partisipasi Murni (APM) di tingkat SD sebesar 94,7\%, sedangkan di tingkat SMP 66,5\%. Proporsi anak yang memulai dari Kelas 1 hingga mencapai Kelas 5 sebesar $81 \%$, sedangkan proporsi anak yang memulai dari Kelas 1 hingga menamatkan SD sebesar $74,7 \%$. Adapun tingkat melek huruf pada populasi berusia 15 sampai 24 tahun sebanyak 99,4\% dengan rasio melek huruf perempuan terhadap laki-laki usia 15 sampai 24 tahun sebesar 99,9\%. Rasio anak perempuan terhadap anak laki-laki di tingkat SD, SMP, dan SMA berturut-turut sebesar 100\%, 99,4\%, dan 100\% (Bappenas 2007).

Berdasarkan target Millennium Development Goals (MDGs), diketahui bahwa posisi bidang pendidikan di Indonesia dalam hal partisipasi di tingkat SD (APM) sudah mencapai $94,7 \%$ dan proporsi siswa yang tamat SD mencapai $74,7 \%$ dan terus meningkat sesuai target. Namun partisipasi di tingkat SMP (APM) masih belum memenuhi target, yaitu masih mencapai 
$66,5 \%$ dan meningkat perlahan. Sedangkan rasio anak perempuan di SD $(100 \%)$ dan SMP $(99,4 \%)$ sudah mencapai target dan mengalami banyak kemajuan.

Kualitas sistem pendidikan bergantung pada kualitas sumberdaya manusia dan sumberdaya fisik, materi pembelajaran, pengetahuan dan infrastruktur sekolah, manajemen sekolah dan pemerintah. Faktor lingkungan yang berhubungan dengan ketersediaan input adalah dukungan orangtua, waktu yang tersedia untuk sekolah dan pekerjaan rumah serta harapan dari bersekolah (UNESCO 2005). Gary S Becker dalam bukunya The Essence of Becker menyatakan bahwa kualitas modal manusia (the quality of human capital) tergantung pada investasi yang diberikan melalui pendidikan individu baik pendidikan formal di sekolah maupun pendidikan nonformal (Schwartz \& Scott 1994). Dengan demikian keluarga memegang peranan penting dalam menentukan kualitas modal manusia.

Keluarga menurut sejumlah ahli adalah sebagai unit sosial-ekonomi terkecil dalam masyarakat yang merupakan landasan dasar dari semua institusi, merupakan kelompok primer yang terdiri dari dua atau lebih orang yang mempunyai jaringan interaksi interpersonal, hubungan darah, hubungan perkawinan, maupun adopsi (UU Nomor 10 Tahun 1992 Pasal 1 Ayat 10; Khairuddin (1985); Landis (1989); Day et al. (1995); Gelles (1995); Ember \& Ember (1996); Vosler (1996)). Sebagai unit terkecil dalam masyarakat, keluarga memiliki kewajiban untuk memenuhi kebutuhan-kebutuhan anaknya yang meliputi agama, psikologi, makan dan minum, dan sebagainya. Adapun tujuan membentuk keluarga adalah untuk mewujudkan kesejahteraan bagi anggota keluarganya (Landis 1989; BKKBN 1992).

Secara umum tulisan ini bertujuan untuk mengetahui pengaruh karakteristik sosial ekonomi keluarga terhadap pola asuh belajar siswa sekolah dasar dan menengah pertama. Secara khusus tulisan ini bertujuan untuk: (1) mengetahui karakteristik sosial ekonomi dan demografi keluarga contoh, (2) mengetahui fasilitas pendidikan di rumah, (3) mengetahui pola asuh belajar pada siswa, dan (4) menganalisis pengaruh karakteristik sosial ekonomi keluarga terhadap pola asuh belajar siswa sekolah dasar dan menengah pertama dengan uji Structural Equation Modelling (SEM).
Kerangka pemikiran penelitian yang akan diuji dalam artikel ini tersaji pada Gambar 1.

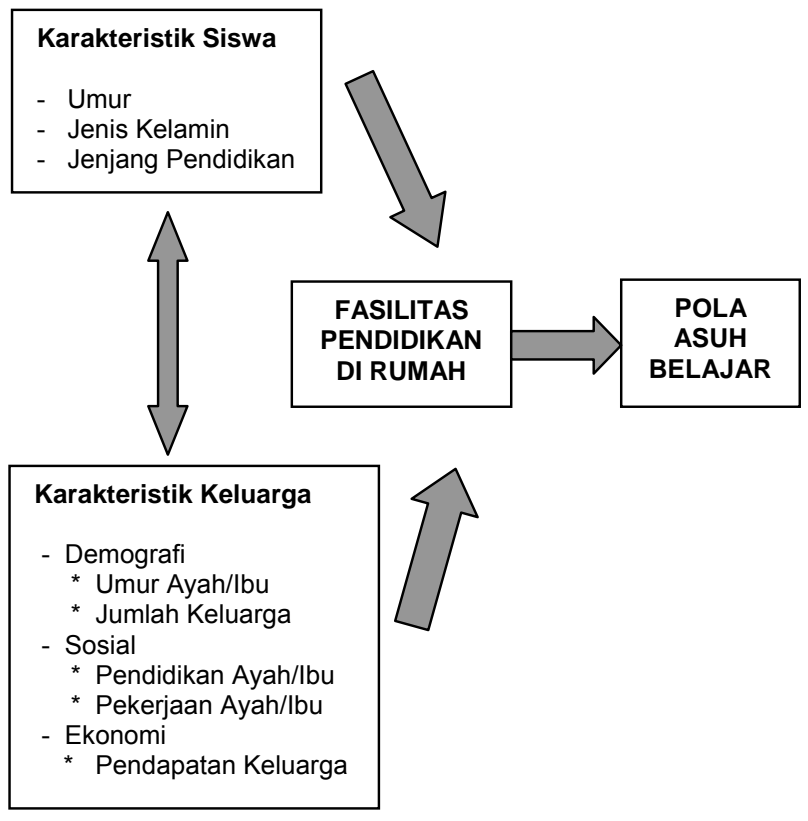

Gambar 1. Kerangka pemikiran

\section{METODE}

\section{Desain, Lokasi, dan Waktu}

Penelitian ini menggunakan data sekunder dari penelitian Puspitawati et al. (2009) dengan judul "Parent Satisfaction Survey of Basic Education Services Provided by Decentralised School System" yang didanai oleh PRMAP-ADB dan Bappenas kerjasama dengan LPPM-IPB. Penelitian menggunakan desain cross-sectional study. Penelitian dilaksanakan di 4 (empat) kecamatan di Kabupaten Indramayu, Provinsi Jawa Barat, yaitu Kecamatan Indramayu, Sindang, Karangampel dan Kandanghaur.

\section{Cara Pengambilan Contoh dan Jenis Data}

Responden pada penelitian ini terdiri atas 400 orangtua siswa yang terdiri atas: (1) ayah/wali laki-laki saja sebanyak 70 keluarga, (2) ibu/wali perempuan saja sebanyak 198 keluarga, dan (3) kedua orangtua lengkap yang meliputi ayah/wali laki-laki dan ibu/wali perempuan sebanyak 132 keluarga. Orangtua siswa yang diwawancara berasal dari 40 sekolah yang 
terdiri atas 16 sekolah dasar dan 24 sekolah menengah pertama. Orangtua siswa diwawancara dengan mempergunakan kuesioner terstruktur untuk menangkap data kuantitatif dan dilaksanakan di rumah orangtua. Variabel-variabel dalam kuesioner meliputi: (1) karakteristik sosial ekonomi keluarga, (2) karakteristik anak, (3) fasilitas pendidikan di rumah yang terdiri atas 7 item pertanyaan dengan skala ordinal (1-2), dan (4) pola asuh belajar yang terdiri atas 8 item pertanyaan dengan skala ordinal (1-5). Berdasarkan uji reliabilitas Cronbach Alpha, diketahui bahwa assessment fasilitas pendidikan di rumah diukur berdasarkan 7 item pertanyaan dengan skala likert 1 (tidak ada) sampai 2 (ada) menunjukkan hasil reliabilitasnya adalah 0,56 . Sementara itu, Cronbach Alpha untuk assessment pola asuh belajar diukur berdasarkan 9 item pertanyaan dengan skala likert 1 (tidak pernah) sampai 3 (sering) adalah 0,78.

\section{Pengolahan dan Analisis Data}

Data dianalisis secara deskriptif. Adapun analisis pengaruh karakteristik sosial ekonomi keluarga terhadap pola asuh belajar siswa sekolah dasar dan menengah pertama dilakukan dengan menggunakan analisis Structural Equation Modelling (SEM).

\section{HASIL DAN PEMBAHASAN}

\section{Karakteristik Sosial Ekonomi \\ Demografi Keluarga}

Diketahui bahwa dua pertiga dari ayah siswa berumur sekitar 36-55 tahun dengan rata-rata umur 45,6 tahun dan simpangan baku 8,9 tahun. Ditemukan juga bahwa dua pertiga dari ibu siswa berumur sekitar 31 - 50 tahun dengan rata-rata umur 41,3 tahun dan simpangan baku 8,6 tahun (Tabel 1).

Dari Tabel 2, diketahui bahwa sekitar kurang dari $10 \%$ dari ayah siswa dan sekitar $20 \%$ dari ibu siswa tidak pernah mengikuti sekolah di pendidikan formal. Hasil penelitian menunjukkan bahwa setengah dari ayah dan ibu siswa mempunyai tingkat pendidikan sampai dengan tamat SMP. Ditemukan juga bahwa sekitar $20 \%$ ayah dan $14 \%$ ibu siswa mempunyai tingkat pendidikan sampai dengan tamat SMA. Adapun rata-rata lama pendidikan ayah dan ibu siswa adalah berturut-turut 7,4 dan 6,1 tahun.
Tabel 1. Sebaran contoh berdasarkan kisaran umur ayah dan ibu contoh

\begin{tabular}{cccccc}
\hline No & $\begin{array}{c}\text { Kisaran } \\
\text { Umur } \\
\text { (Tahun) }\end{array}$ & \multicolumn{2}{c}{$\begin{array}{c}\text { Ayah/Wali } \\
\text { Laki-laki } \\
\text { (n=350) }\end{array}$} & \multicolumn{2}{c}{$\begin{array}{c}\text { Ibu/Wali } \\
\text { Perempuan } \\
\text { (n=381) }\end{array}$} \\
\cline { 3 - 6 } & $\mathbf{n}$ & $\mathbf{9}$ & \multicolumn{1}{c}{$\mathbf{n}$} & $\%$ \\
\hline 1 & $\leq 20$ & 0 & 0,0 & 1 & 0,3 \\
2 & $21-25$ & 2 & 0,5 & 6 & 1,5 \\
3 & $26-30$ & 12 & 3,0 & 19 & 4,8 \\
4 & $31-35$ & 28 & 7,0 & 73 & 18,3 \\
5 & $36-40$ & 77 & 19,3 & 109 & 27,3 \\
6 & $41-45$ & 63 & 15,8 & 81 & 20,3 \\
7 & $46-50$ & 74 & 18,5 & 50 & 12,5 \\
8 & $51-55$ & 50 & 12,5 & 20 & 5,0 \\
9 & $>55$ & 44 & 11,0 & 22 & 5,5 \\
\hline Total Rata-rata \pm Std & $45,6 \pm 8,9$ & $41,3 \pm 8,6$ \\
\hline
\end{tabular}

Tabel 2. Sebaran contoh berdasarkan tingkat pendidikan ayah dan ibu

\begin{tabular}{|c|c|c|c|c|c|}
\hline \multirow[t]{2}{*}{ No } & \multirow[t]{2}{*}{$\begin{array}{c}\text { Tingkat } \\
\text { Pendidikan }\end{array}$} & \multicolumn{2}{|c|}{$\begin{array}{l}\text { Ayah/Wali } \\
\text { Laki-laki } \\
(n=350)\end{array}$} & \multicolumn{2}{|c|}{$\begin{array}{c}\text { Ibu/Wali } \\
\text { Perempuan } \\
(n=381)\end{array}$} \\
\hline & & $\mathbf{n}$ & $\%$ & $\mathrm{n}$ & $\%$ \\
\hline \multirow{2}{*}{$\begin{array}{l}1 \\
2\end{array}$} & Tidak sekolah & 35 & 8,8 & 74 & 18,5 \\
\hline & $\begin{array}{l}\text { Tidak tamat } \\
\text { SD }\end{array}$ & 87 & 21,8 & 87 & 21,8 \\
\hline \multirow{2}{*}{$\begin{array}{l}3 \\
4\end{array}$} & Tamat SD & 77 & 19,3 & 83 & 20,8 \\
\hline & $\begin{array}{l}\text { Tidak Tamat } \\
\text { SMP }\end{array}$ & 9 & 2,3 & 11 & 2,8 \\
\hline \multirow{2}{*}{$\begin{array}{l}5 \\
6\end{array}$} & Tamat SMP & 23 & 5,8 & 41 & 10,3 \\
\hline & $\begin{array}{l}\text { Tidak Tamat } \\
\text { SMA }\end{array}$ & 6 & 1,5 & 4 & 1,0 \\
\hline \multirow{2}{*}{$\begin{array}{l}7 \\
8\end{array}$} & Tamat SMA & 82 & 20,5 & 56 & 14,0 \\
\hline & $\begin{array}{l}\text { Perguruan } \\
\text { Tinggi }\end{array}$ & 31 & 7,8 & 25 & 6,3 \\
\hline \multicolumn{2}{|c|}{$\begin{array}{c}\text { Total Rata-rata } \pm \text { Std } \\
\text { (th) }\end{array}$} & \multicolumn{2}{|c|}{$7,4 \pm 4,8$} & \multicolumn{2}{|c|}{$6,1 \pm 4,7$} \\
\hline
\end{tabular}

Temuan lain menunjukkan bahwa ratarata jumlah anggota keluarga siswa adalah 6 orang dengan kisaran sebanyak 2-16 orang. Sementara itu, $90 \%$ keluarga siswa mempunyai jumlah anggota keluarga hingga 8 orang.

Berdasarkan Tabel 3, diketahui bahwa kisaran pendapatan/kapita/bulan pada keluarga siswa adalah sebesar Rp 10.000,00 sampai $\mathrm{Rp} 6.250 .000,00$, dengan rata-rata pendapatan/kapita/bulan sebesar Rp 294.042,00 dan simpangan baku sebesar 549.356. Menurut Badan Pusat Statistik (2008) garis kemiskinan di Provinsi Jawa Barat adalah Rp 176.216,00/kap/bulan. Dengan demikian, sekitar $80 \%$ keluarga siswa dalam penelitian ini hidup di bawah garis kemiskinan yaitu keluarga yang mempunyai pendapatan/kapita/bulan Rp 176.216,00. 
Tabel 3. Sebaran contoh berdasarkan pendapatan/kapita/bulan pada keluarga

\begin{tabular}{|c|c|c|c|}
\hline \multirow[b]{2}{*}{ No } & \multirow{2}{*}{$\begin{array}{c}\text { Kisaran Pendapatan/ } \\
\text { Kap/Bulan } \\
\text { (Rp/Bulan) }\end{array}$} & \multicolumn{2}{|c|}{ Jumlah $(n=398)$} \\
\hline & & $\mathbf{n}$ & $\%$ \\
\hline 1 & $\leq 50.000$ & 67 & 16,8 \\
\hline 2 & $50.001-100.000$ & 98 & 24,5 \\
\hline 3 & $100.001-150.000$ & 57 & 41,3 \\
\hline 4 & $150.001-200.000$ & 40 & 10,0 \\
\hline 5 & $200.001-250.000$ & 34 & 8,5 \\
\hline 6 & $250.001-300.000$ & 14 & 3,5 \\
\hline 7 & $300.001-350.000$ & 7 & 1,8 \\
\hline 8 & $350.001-400.000$ & 12 & 3,0 \\
\hline 9 & $>400.000$ & 69 & 17,3 \\
\hline \multicolumn{2}{|c|}{ Total Rata-rata \pm Std } & 294.0 & 9.356 \\
\hline
\end{tabular}

Ket: Sebanyak 2 keluarga yang tidak mempunyai pendapatan dan ditanggung oleh keluarga besarnya.

\section{Fasilitas Pendidikan di Rumah}

Hasil penelitian ini seperti yang tersaji pada Tabel 4, menunjukkan bahwa sebagian keluarga siswa mempunyai fasilitas pendidikan di rumah berupa kamar/ruang belajar $(69,8 \%)$, kamus $(65 \%)$, dan buku-buku pelajaran (92,3\%). Hasil penelitian juga menunjukkan bahwa hampir setengah keluarga siswa mempunyai fasilitas meja belajar bersama (48,3\%). Adapun fasilitas seperti kalkulator hanya dimiliki oleh kurang dari sepertiga keluarga dan fasilitas seperti mesin tik/komputer hanya dimiliki oleh sekitar sepersepuluh keluarga.

Apabila dibedakan antara kelompok siswa SD dan SMP, maka terlihat perbedaan yang signifikan dalam penyediaan fasilitas pendidikan di rumah siswa, yaitu fasilitas yang lebih baik pada kelompok siswa SD dibandingkan dengan kelompok siswa SMP, khususnya dalam hal kamar/ruang belajar, kalkulator, kamus, dan buku-buku pelajaran. Apabila fasilitas pendidikan di rumah dikaitkan dengan tingkat sosial ekonomi keluarga, maka Tabel 5 menyajikan sebaran responden berdasarkan kategori pendapatan dan fasilitas pendidikan di rumah.

Berdasarkan uji Korelasi RankSpearman, terlihat bahwa tingkat pendapatan keluarga mempunyai hubungan positif dan signifikan dengan kelengkapan fasilitas pendidikan di rumah $\left(r=0,43^{* *}\right.$; $p=0,01)$. Hal ini berarti bahwa apabila keluarga siswa SD maupun SMP semakin sejahtera secara ekonomi, maka keluarga tersebut cenderung untuk memberikan fasilitas yang makin baik untuk anaknya di rumah, baik berupa kamar/ruang belajar, kalkulator, kamus maupun buku-buku pelajaran.

Hasil analisis statistik juga menunjukkan bahwa kelengkapan fasilitas pendidikan di rumah berhubungan positif signifikan dengan lama pendidikan ibu $\left(r=0,47^{* *} ; p=0,01\right)$ dan lama pendidikan ayah $\left(r=0,48^{* *} ; p=0,01\right)$. Hal ini berarti bahwa semakin tinggi pendidikan orangtua akan meningkatkan kesadaran akan pentingnya pendidikan dasar anaknya, sehingga fasilitas belajar di rumah cenderung untuk semakin diperhatikan dan diprioritaskan oleh para orangtua yang berpendidikan.

Tabel 4. Sebaran contoh berdasarkan ketersediaan fasilitas pendidikan di rumah beserta kualitasnya

\begin{tabular}{|c|c|c|c|c|c|c|c|}
\hline \multirow{2}{*}{ No } & \multirow{2}{*}{ Fasilitas Pendidikan } & \multirow{2}{*}{$\begin{array}{c}\text { Ada }(n=400) \\
\%\end{array}$} & \multicolumn{5}{|c|}{ Kualitas Fasilitas Pendidikan } \\
\hline & & & 1 & 2 & 3 & 4 & 5 \\
\hline 1 & Meja belajar bersama & 48,3 & 2,1 & 21,8 & 46,6 & 28,0 & 1,6 \\
\hline 2 & Meja belajar khusus untuk anak & 29,0 & 0,9 & 12,9 & 41,4 & 37,9 & 2,0 \\
\hline $3^{*}$ & Kamar/ ruang belajar & 69,8 & 4,7 & 28,0 & 32,0 & 13,0 & 2,0 \\
\hline $4^{*}$ & Kalkulator & 28,8 & 4,3 & 13,9 & 36,5 & 33,0 & 12,2 \\
\hline 5 & Mesin tik/komputer & 12,8 & 5,9 & 5,9 & 9,8 & 45,1 & 33,3 \\
\hline $6^{*}$ & Kamus & 65,0 & 1,2 & 20,0 & 42,3 & 27,7 & 8,8 \\
\hline $7^{*}$ & Buku-buku pelajaran & 92,3 & 1,6 & 25,5 & 28,7 & 30,9 & 12,3 \\
\hline
\end{tabular}


Tabel 5. Sebaran contoh berdasarkan kategori pendapatan dan kelengkapan fasilitas pendidikan di rumah

\begin{tabular}{|c|c|c|c|c|c|c|c|c|}
\hline \multirow{3}{*}{ Tingkat Sosial Ekonomi Keluarga } & \multicolumn{6}{|c|}{ Fasilitas Pendidikan Di Rumah } & \multirow{2}{*}{\multicolumn{2}{|c|}{ Total }} \\
\hline & \multicolumn{2}{|c|}{$\begin{array}{c}\text { Kurang Lengkap } \\
(7-9,3)\end{array}$} & \multicolumn{2}{|c|}{$\begin{array}{c}\text { Cukup Lengkap } \\
(9,4-11,7)\end{array}$} & \multicolumn{2}{|c|}{$\begin{array}{c}\text { Lengkap } \\
(11,8-14,2)\end{array}$} & & \\
\hline & $\mathbf{n}$ & $\%$ & $\mathrm{n}$ & $\%$ & $\mathbf{n}$ & $\%$ & $\mathbf{n}$ & $\%$ \\
\hline 1. Miskin $(<1 \mathrm{GK})$ & 95 & 79,2 & 112 & 63,3 & 31 & 30,1 & 238 & 59,5 \\
\hline 2. Hampir Miskin (1GK-2GK) & 21 & 17,5 & 36 & 20,3 & 22 & 21,4 & 79 & 19,8 \\
\hline 3. Menengah Atas (> 2GK) & 4 & 3,3 & 29 & 16,4 & 50 & 48,5 & 83 & 20,7 \\
\hline Total & 120 & 100,0 & 177 & 100,0 & 103 & 100,0 & 400 & 100,0 \\
\hline
\end{tabular}

Ket : GK = Garis Kemiskinan Jawa Barat tahun 2008 sebesar Rp 176.216,00

Pola Asuh Belajar pada Siswa

Dari Tabel 6, dapat diketahui bahwa secara umum pola asuh belajar yang lakukan oleh orangtua terhadap anaknya sudah cukup menunjukkan usaha mendukung dan memfasilitasi proses belajar anak. Hal ini ditunjukkan dengan bukti bahwa: 1) Sebanyak $38 \%$ orangtua/wali menetapkan waktu belajar untuk anaknya, bahkan 33,2\% orangtua/wali sering/selalu menetapkan waktu belajar untuk anaknya; 2) sebanyak $79,7 \%$ orangtua/wali menanyakan hasil tes/ulangan anaknya, dan 34\% diantaranya sering/selalu menanyakan hasil tes/ulangan; 3) sebanyak $74,2 \%$ orangtua/wali memberi pujian/penghargaan/hadiah apabila anak mendapat nilai yang baik dan $30,8 \%$ diantaranya sering/selalu memberikan pujiannya; 4) sebanyak dua pertiga orangtua/wali berdiskusi dengan anaknya tentang proses belajar dengan guru di sekolah $(82,2 \%)$, perlakuan guru terhadap diri anaknya $(66,2 \%)$ dan kualitas fasilitas di sekolah $(63 \%)$.

Namun demikian, ada beberapa usaha yang masih belum optimal, artinya para orangtua/wali masih belum memaksimalkan fungsi pengasuhan anak khususnya dalam aspek belajar, yang ditunjukkan dengan bukti bahwa: 1) sebanyak $57 \%$ orangtua/wali tidak pernah menemani/mengecek anaknya belajar; 2) sebanyak sepertiga orangtua/wali memarahi anaknya apabila anak menghadapi kegagalan $(34,8 \%)$ dan/atau kalau anaknya tidak mau belajar $(32,8 \%)$.

Apabila dibedakan antara kelompok siswa SD dan SMP, maka terlihat adanya perbedaan dalam pola asuh belajar, yaitu pola asuh yang lebih baik pada kelompok siswa SD dibandingkan dengan kelompok siswa SMP dalam hal orangtua/wali menetapkan waktu belajar, menanyakan hasil tes/ulangan, menemani anak belajar, memberikan pujian/penghargaan apabila mendapat nilai baik dan memarahi apabila anak tidak mau belajar. Hal ini dapat dimengerti karena usia SMP adalah usia anak remaja yang dianggap orangtua sudah cukup mandiri dalam melakukan kegiatan sehari-hari, sehingga derajat kekuatan orangtua terhadap pola asuh belajar anak kelompok SMP relatif lebih rendah dibandingkan dengan pola asuh belajar anak kelompok SD.

Tabel 6. Pola asuh belajar siswa SD dan SMP di Kabupaten Indramayu $(n=400)$

\begin{tabular}{|c|c|c|c|c|c|c|}
\hline \multirow{2}{*}{ No } & \multirow{2}{*}{ Pertanyaan } & \multicolumn{5}{|c|}{ Jawaban (\%) } \\
\hline & & 1 & 2 & 3 & 4 & 5 \\
\hline $1^{*}$ & Apakah orangtua menetapkan waktu belajar untuk anaknya? & 38,0 & 16,3 & 10,5 & 20,8 & 14,5 \\
\hline $2^{*}$ & Apakah orangtua menanyakan hasil tes/ulangan anaknya? & 20,3 & 19,0 & 16,8 & 27,5 & 16,5 \\
\hline $3^{*}$ & Apabila anak belajar, apakah orangtua menemani? & 57,0 & 18,3 & 8,8 & 8,5 & 7,5 \\
\hline 4 & $\begin{array}{l}\text { Apabila anak menghadapi kegagalan, apakah orangtua } \\
\text { memarahi anak? }\end{array}$ & 34,8 & 30,0 & 12,5 & 17,3 & 5,5 \\
\hline $5^{*}$ & $\begin{array}{l}\text { Apabila anak mendapat nilai yang baik, apakah orangtua } \\
\text { memberi pujian/ penghargaan/ hadiah? }\end{array}$ & 25,8 & 23,0 & 20,5 & 20,5 & 10,3 \\
\hline $6^{*}$ & Apabila anak tidak mau belajar, apakah orangtua memarahi? & 32,8 & 26,3 & 15,3 & 19,3 & 6,5 \\
\hline 7 & $\begin{array}{l}\text { Apakah orangtua berdiskusi dengan anaknya tentang proses } \\
\text { belajar dengan guru di sekolah? }\end{array}$ & 27,8 & 30,0 & 14,0 & 24,0 & 4,3 \\
\hline 8 & $\begin{array}{l}\text { Apakah orangtua berdiskusi kepada anak tentang perlakuan guru } \\
\text { terhadap diri anaknya? }\end{array}$ & 33,8 & 27,0 & 13,8 & 22,5 & 3,0 \\
\hline 9 & $\begin{array}{l}\text { Apakah orangtua berdiskusi pada anak tentang kualitas fasilitas } \\
\text { sekolah? }\end{array}$ & 37,0 & 29,3 & 12,3 & 20,0 & 1,5 \\
\hline
\end{tabular}

Ket: 1=tidak pernah; 2=jarang; 3=kadang-kadang; 4=sering; 5=sering sekali

* Berbeda nyata pada $p<0,10$ antara siswa SD dan SMP 
Berdasarkan hasil tabulasi pada Tabel 4 dan Tabel 6, maka dapat diketahui bahwa sekitar dua pertiga siswa SD dan SMP sudah mempunyai kamar/ruang belajar dengan fasilitas meja belajar bersama. Pada umumnya siswa sudah mempunyai bukubuku pelajaran dan kamus. Sementara, fasilitas seperti mesin tik, komputer dan kalkulator masih dimiliki oleh sebagian kecil siswa. Hasil penelitian ini menunjukkan bahwa pihak keluarga sudah berusaha untuk memfasilitasi pendidikan anaknya di rumah dan melakukan pola asuh belajar bagi anakanaknya dalam tingkatan cukup baik. Seperti dinyatakan oleh Hurlock (1973) iklim dan suasana rumah ditunjukkan oleh status sosial-ekonomi, aspirasi dan pekerjaan orangtua yang berpengaruh pada outcome anak-anaknya.

Selanjutnya, apabila dianalisis berdasarkan analisis gender, maka ditemukan adanya perbedaan yang signifikan tentang pola asuh belajar pada siswa laki-laki dan perempuan. Siswa lakilaki cenderung mendapat perlakuan orangtua yang memarahi apabila anak menghadapi kegagalan dibandingkan dengan siswa perempuan. Sebaliknya, siswa perempuan mendapatkan pola asuh belajar yang lebih baik dibandingkan dengan siswa laki-laki dalam hal orangtua/wali menanyakan hasil tes/ulangan, memberikan pujian atau penghargaan apabila mendapat nilai baik, berdiskusi tentang proses belajar dengan guru di sekolah, perlakuan guru dan kualitas fasilitas sekolah. Hubungan pola asuh belajar dikaitkan dengan tingkat sosial ekonomi keluarga dapat dilihat pada Tabel 7 .

Tabel 8 menyajikan uji beda mean variabel-variabel penelitian antara siswa SD dan SMP. Hasil penelitian menunjukkan bahwa tingkat pendidikan ibu, total pendapatan keluarga per bulan, dan pola asuh belajar anak yang masih didampingi/diawasi oleh orangtua lebih tinggi secara nyata pada siswa SD dibandingkan dengan siswa SMP.

\section{Analisis SEM tentang Pengaruh Karakteristik Sosial Ekonomi Keluarga terhadap Pola Asuh Belajar Siswa SD dan SMP}

Hasil yang tersaji pada Gambar 2 menunjukkan bahwa angka pada nilai GFI (Goodness of Fit Index) adalah 0,76 untuk tingkat SD, 0,89 untuk tingkat SMP, dan 0,85 untuk total. Dengan demikian, model-model yang disusun tersebut menurut Bollen (1989) masih dapat dikatakan cukup cocok atau fit dengan data yang dikumpulkan, meskipun masih tergolong sangat rendah.

Hasil analisis yang tersaji pada Gambar 2 dan Tabel 9 menunjukkan bahwa: (i) variabel laten karakteristik sosial keluarga yang terdiri atas indikator pendidikan ayah $\left(\lambda y_{1}=1,00^{*} ; \quad p=0,05 ;\right.$ masing-masing untuk tingkat SD, SMP, dan total) dan indikator pendidikan ibu $\left(\lambda y_{2}=-0,34^{*} ; p=0,05\right.$ untuk tingkat SD; $\lambda y_{2}=-0,43^{*} ; p=0,05$ untuk tingkat SMP; dan $\lambda y_{2}=-0,39^{*} ; p=0,05$ untuk total); (ii) variabel laten karakteristik ekonomi keluarga

Tabel 7. Sebaran responden berdasarkan kategori pendapatan dan pola asuh belajar

\begin{tabular}{|c|c|c|c|c|c|c|c|c|}
\hline \multirow{3}{*}{$\begin{array}{l}\text { Tingkat Sosial Ekonomi Keluarga } \\
\text { (Pendapatan/Kap/Bulan) }\end{array}$} & \multicolumn{6}{|c|}{ Pola Asuh Belajar Siswa } & \multirow{2}{*}{\multicolumn{2}{|c|}{ Total }} \\
\hline & \multicolumn{2}{|c|}{$\begin{array}{l}\text { Kurang Baik } \\
(9-21)\end{array}$} & \multicolumn{2}{|c|}{$\begin{array}{l}\text { Cukup Baik } \\
(21,1-33,1)\end{array}$} & \multicolumn{2}{|c|}{$\begin{array}{l}\text { Baik Sekali } \\
(33,2-45,2)\end{array}$} & & \\
\hline & $\mathbf{n}$ & $\%$ & n & $\%$ & $\mathbf{n}$ & $\%$ & $\mathbf{n}$ & $\%$ \\
\hline 1. Miskin $(<1 \mathrm{GK})$ & 105 & 70,9 & 122 & 56,7 & 11 & 4,6 & 238 & 59,5 \\
\hline 2. Hampir Miskin (1GK-2GK) & 30 & 20,3 & 42 & 19,6 & 7 & 18,9 & 79 & 19,8 \\
\hline 3. Menengah Atas (> 2GK) & 13 & 8,8 & 51 & 23,7 & 19 & 51,5 & 83 & 20,7 \\
\hline Total & 148 & 100,0 & 215 & 100,0 & 37 & 100,0 & 400 & 100,0 \\
\hline
\end{tabular}

Keterangan: GK = Garis Kemiskinan Jawa Barat tahun 2008 Rp 176.216,00

Tabel 8. Uji beda rata-rata variabel-variabel penelitian antara siswa SD dan SMP

\begin{tabular}{clrrrr}
\hline \multirow{2}{*}{ No } & \multicolumn{1}{c}{ Variabel } & \multicolumn{2}{c}{ Mean } & \multirow{2}{*}{ T-value } & P \\
\cline { 3 - 5 } & Pendidikan Ayah & 4,58 & 5,18 & $-0,710$ & 0,48 \\
2 & Pendidikan Ibu & $\mathbf{7 , 2 4}$ & 5,50 & 3,530 & $\mathbf{0 , 0 0}$ \\
3 & Pendapatan Keluarga & $\mathbf{1 , 9 1 7 , 5 5 1}$ & $1,148,340$ & 2,203 & $\mathbf{0 , 0 3}$ \\
4 & Fasilitas Pendidikan di Rumah & 22,31 & 21,10 & 1,391 & 0,17 \\
5 & Pola Asuh Belajar & $\mathbf{2 4 , 5 8}$ & 22,48 & 3,215 & $\mathbf{0 , 0 0}$ \\
\hline
\end{tabular}




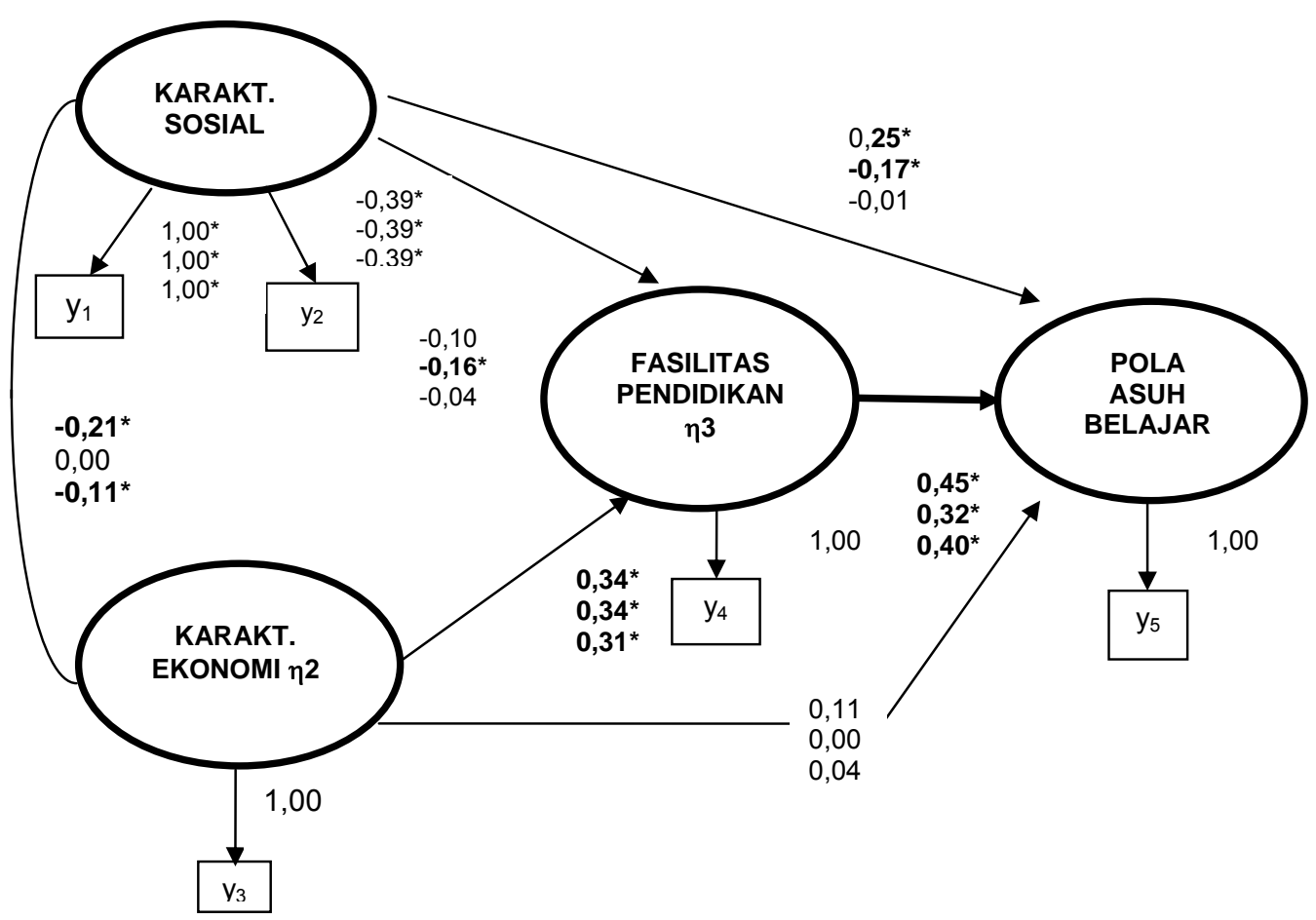

Keterangan:

- $\quad$ Baris 1=SD

- $\quad$ Baris 2= SMP

- $\quad$ Baris $3=$ Total

- $\quad X 2(p)=242 ; 91,16 ; 245,37$

- $P=0,00 ; 0,00 ; 0,00$

- $\mathrm{df} \quad=3 ; 3 ; 3$

- $\mathrm{GFI}=0,76 ; 0,89 ; 0,85$

- $\mathrm{n} \quad=160 ; 241 ; 401$

Gambar 2. Model lengkap pengaruh karakteristik sosial ekonomi keluarga terhadap pola asuh belajar $(n=250)$

berupa indikator pendapatan keluarga per bulan $\left(\lambda y_{3}=1,00 * ; p=0,05\right.$, masing-masing untuk tingkat SD, SMP, dan total); (iii) variabel laten fasilitas belajar di rumah berupa indikator komposit fasilitas pendidikan di rumah $\left(\lambda y_{4}=1,00^{*} ; p=0,05\right.$; masing-masing untuk tingkat SD, SMP, dan total); dan variabel laten pola asuh belajar terdiri atas indikator komposit pola asuh belajar $\left(\lambda y_{5}=1,00^{*} ; p=0,05\right.$, masing-masing untuk tingkat SD, SMP dan total).

Data Tabel 9 menunjukkan bahwa pola asuh belajar dipengaruhi oleh:

1. Secara langsung positif signifikan $\left(\beta=0,25^{\star}\right)$ oleh karakteristik sosial keluarga pada kelompok siswa SD; dan secara langsung negatif signifikan $\left(\beta=-0,17^{*}\right)$ dan secara tidak langsung negatif signifikan $(\beta=-$
$0,05^{*}$ ) oleh karakteristik sosial keluarga pada kelompok siswa SMP.

2. Secara tidak langsung positif signifikan oleh karakteristik ekonomi keluarga $\left(\beta=0,15^{*}\right.$ untuk kelompok siswa SD; $\beta=0,11^{*}$ untuk kelompok siswa SMP; dan $\beta=0,12^{*}$ untuk total)

3. Secara langsung positif signifikan oleh fasilitas pendidikan di rumah $\left(\beta=0,45^{*}\right.$ untuk kelompok siswa SD; $\beta=0,32^{*}$ untuk kelompok siswa SMP; dan $\beta=0,40^{*}$ untuk total).

Berdasarkan data yang disajikan pada Tabel 9 diketahui bahwa ada perbedaan pengaruh dari karakteristik sosial ekonomi keluarga terhadap pola asuh belajar antara tingkat siswa sekolah dasar dan menengah pertama. Pertama, pengaruh langsung 
karakteristik sosial keluarga terhadap pola asuh belajar pada siswa SD bersifat positif, sedangkan karakteristik sosial keluarga berpengaruh langsung maupun tidak langsung terhadap pola asuh belajar pada siswa SMP bersifat negatif. Kedua, adalah pengaruh tidak langsung signifikan positif dari karakteristik ekonomi keluarga terhadap pola asuh belajar pada tingkat SD adalah lebih tinggi dibandingkan tingkat SMP. Ketiga, adalah pengaruh langsung signifikan positif dari fasilitas pendidikan di rumah terhadap pola asuh belajar pada tingkat SD adalah lebih tinggi dibandingkan tingkat SMP. Dengan demikian, dapat dikatakan bahwa keadaan sosial ekonomi pendidikan keluarga yang mempunyai anak SD adalah lebih tinggi dibandingkan dengan keadaan sosial ekonomi pendidikan keluarga yang mempunyai anak SMP. Hal ini ditunjang oleh hasil uji beda rata-rata antara tingkat SD dan SMP yang menunjukkan pendapatan keluarga dan pola asuh belajar siswa SD yang lebih tinggi dibandingkan dengan siswa SMP.

Hasil penelitian ini mengindikasikan bahwa semakin baik fasilitas belajar di rumah dan semakin tinggi keadaan ekonomi keluarga berpengaruh secara positif terhadap pola asuh belajar siswa. Dengan kata lain, semakin tinggi keluarga menginvestasikan sumberdaya keluarga dalam bentuk mengalokasikan keadaan ekonomi keluarga ke dalam fasilitas belajar anak, maka akan semakin baik pola asuh belajar yang dilakukan oleh orangtua kepada anaknya. Pola asuh belajar yang baik ini diindikasikan oleh keterlibatan orangtua dalam pendampingan dan pengawasan belajar anaknya.

Sesuai dengan pendapat Gary S Becker dalam bukunya The Essence of Becker yang menyatakan bahwa kualitas modal manusia (the quality of human capital) tergantung pada investasi yang diberikan melalui pendidikan individu baik pendidikan formal di sekolah maupun pendidikan nonformal (Schwartz \& Scott 1994). Dikaitkan dengan hasil penelitian ini maka ada indikasi bahwa orangtua berusaha untuk melakukan investasi kualitas mutu modal manusia melalui penyediaan fasilitas belajar di rumah yang memadai dan keterlibatan orangtua dalam pola asuh belajar anaknya secara optimal, dengan kondisi siswa tingkat SD yang relatif lebih baik dengan siswa tingkat SMP.

Merujuk kembali pada Peraturan Pemerintah (PP) Nomor 21 tahun 1994 yang menyebutkan adanya delapan fungsi keluarga yang terdiri atas fungsi keagamaan, sosial, budaya, cinta kasih, melindungi, reproduksi, sosialisasi dan pendidikan, ekonomi, dan pembinaan lingkungan (BKKBN 1996), maka penelitian ini mengangkat kembali peran orangtua dalam memberikan perlindungan, pendidikan dan pengasuhan yang utama dan pertama kepada anak-anaknya. Sebagaimana dijelaskan oleh Popov et al. (1997) dalam bukunya The Family Virtues Guide, peran orangtua adalah sebagai pengasuh dan pendidikan utama anak dan sebagai pelindung dan penguasa dalam menegakkan peraturan; pemandu dan pembina dalam meningkatkan keterampilan; dan konselor dalam mengarahkan moral anak-anaknya.

Tabel 9. Dekomposisi efek pengaruh karakteristik sosial ekonomi keluarga terhadap pola asuh belajar siswa SD dan SMP

\begin{tabular}{|c|c|c|c|c|c|c|c|c|c|c|}
\hline \multirow{2}{*}{ No } & \multirow{2}{*}{ Variabel Laten } & \multicolumn{3}{|c|}{ SD $(n=160)$} & \multicolumn{3}{|c|}{ SMP (n=241) } & \multicolumn{3}{|c|}{ Total $(n=401)$} \\
\hline & & TE & DE & IE & TE & DE & IE & TE & DE & IE \\
\hline 1 & Fasilitas Pendidikan di Rumah ( $\eta 3)$ & \multicolumn{3}{|c|}{$R^{2}=0,11$} & \multicolumn{3}{|c|}{$R^{2}=0,14$} & \multicolumn{3}{|c|}{$R^{2}=0,10$} \\
\hline a & Karakteristik Sosial Keluarga $(\eta 1)$ & 0,10 & 0,10 & 0,00 & $-0,16^{*}$ & $-0,16^{*}$ & 0,00 & $-0,04$ & $-0,04$ & 0,00 \\
\hline $\mathrm{b}$ & Karakteristik Ekonomi Keluarga ( $\eta 2)$ & $0,34^{*}$ & $0,34^{*}$ & 0,00 & $0,34^{*}$ & $0,34^{*}$ & 0,00 & $0,31 *$ & $0,31^{*}$ & 0,00 \\
\hline 2 & Pola Asuh Belajar $(\eta 4)$ & \multicolumn{3}{|c|}{$R^{2}=0,30$} & \multicolumn{3}{|c|}{$R^{2}=0,15$} & \multicolumn{3}{|c|}{$R^{2}=0,18$} \\
\hline a & Karakteristik Sosial Keluarga $(\eta 1)$ & $0,30 *$ & $0,25^{*}$ & 0,05 & $-0,22^{*}$ & $-0,17^{*}$ & $-0,05^{*}$ & $-0,03$ & $-0,01$ & $-0,02$ \\
\hline b & Karakteristik Ekonomi Keluarga ( $\eta 2)$ & $0,26 *$ & 0,11 & $0,15^{*}$ & $0,11^{*}$ & $0,00 *$ & $0,11^{*}$ & $0,17^{*}$ & 0,05 & $0,12 *$ \\
\hline c & Fasilitas Pendidikan di Rumah ( $\eta 3)$ & $0,45^{*}$ & $0,45^{*}$ & 0,00 & $0,32^{*}$ & $0,32 *$ & 0,00 & $0,40 *$ & $0,40 *$ & 0,00 \\
\hline
\end{tabular}

Keterangan: TE=Efek Total; DE=Efek Langsung; IE=Efek Tidak Langsung; ${ }^{*} \mathrm{p}<0,05$ 


\section{KESIMPULAN DAN SARAN}

\section{Kesimpulan}

Kesimpulan penelitian ini adalah sebagai berikut:

1. Sebagian besar keluarga siswa mempunyai fasilitas pendidikan di rumah berupa kamar/ruang belajar, kamus dan buku-buku pelajaran; Hampir setengah keluarga siswa mempunyai fasilitas meja belajar bersama; Adapun fasilitas seperti kalkulator hanya dimiliki oleh kurang dari sepertiga keluarga dan fasilitas seperti mesin tik/komputer hanya dimiliki oleh sekitar sepersepuluh keluarga.

2. Secara umum pola asuh belajar yang lakukan oleh orangtua terhadap anaknya sudah cukup menunjukkan usaha mendukung dan memfasilitasi proses belajar anak seperti menetapkan waktu belajar untuk anaknya, menanyakan hasil tes/ulangan anaknya, memberi pujian/penghargaan/hadiah apabila anak mendapat nilai yang baik, berdiskusi dengan anaknya tentang proses belajar dengan guru di sekolah, berdiskusi tentang perlakuan guru terhadap diri anaknya dan berdiskusi tentang kualitas fasilitas di sekolah; Namun demikian, ada beberapa usaha yang masih belum optimal, seperti tidak pernah menemani/mengecek anaknya belajar, dan memarahi anaknya apabila anak menghadapi kegagalan dan/atau kalau anaknya tidak mau belajar.

3. Berdasarkan analisis SEM diketahui bahwa pola asuh belajar dipengaruhi secara langsung positif signifikan oleh karakteristik sosial keluarga pada tingkat SD; dan secara langsung negatif dan tidak langsung negatif signifikan oleh karakteristik sosial keluarga pada tingkat SMP; Secara tidak langsung positif signifikan oleh karakteristik ekonomi keluarga pada tingkat SD dan SMP; dan secara langsung positif signifikan oleh fasilitas pendidikan di rumah pada tingkat SD dan SMP; Hasil penelitian mengindikasikan bahwa semakin baik fasilitas belajar di rumah dan semakin tinggi keadaan ekonomi keluarga berpengaruh secara positif terhadap pola asuh belajar siswa. Sehingga, semakin tinggi keluarga menginvestasikan sumberdaya keluarga dalam bentuk mengalokasikan keadaan ekonomi keluarga ke dalam fasilitas belajar anak, maka akan semakin tinggi pola asuh belajar yang dilakukan oleh orangtua kepada anaknya. Pola asuh belajar yang baik ini diindikasikan oleh keterlibatan orangtua dalam pendampingan dan pengawasan belajar anaknya.

\section{Saran}

Saran berdasarkan hasil penelitian ini adalah sebagai berikut:

1. Perlu adanya peningkatan pemahaman dan pengetahuan orangtua terhadap pola asuh belajar anaknya melalui peningkatan kerjasama antara komite dengan sekolah agar agar orangtua dapat berperan aktif untuk meningkatkan fungsi pengasuhan dan penyediaan fasilitas pendidikan di rumahtanya.

2. Siswa pada tingkat SMP perlu mendapat perhatian dari pihak sekolah karena pola asuh belajar orangtua siswa SMP lebih rendah dibandingkan dengan siswa pada tingkat SD.

3. Perlu penelitian lebih lanjut yang menganalisis dampak pola asuh belajar terhadap prestasi pendidikan anaknya.

\section{DAFTAR PUSTAKA}

Badan Koordinasi Keluarga Berencana Nasional [BKKBN]. 1992. Undangundang Republik Indonesia nomor 10 tahun 1992 tentang perkembangan kependudukan dan pembangunan keluarga sejahtera. Jakarta: BKKBN. 1996. Situs Informasi Kesehatan Seksual dan Sosial Remaja: Cerita Remaja Indonesia. www.bkkbn.go.id [29 April 2006].

Badan Pusat Statistik [BPS]. 2008. Profil Daerah Kabupaten Indramayu 2008.

Bappenas. 2007. Let's Speak Out for MDGs: Achieving the Millennium Development Goals in Indonesia 2007/2008. (Prepared by MDGs'Project-Bappenas UNDP).

Bollen KA. 1989. Structural Equations with Latent Variables. New York: John Wiley \& Sons.

Day RD, Gilbert KR, Settles BH, Burr WR. 1995. Research and Theory in Family Science. California: Brooks/Cole Publishing Company.

Departemen Pendidikan Nasional. 2006. Indonesia: Educational Statistics in Brief 2005/2006. 
Ember CR, Ember M. 1996. Cultural Anthropology ( $\left.8^{\text {th }} \mathrm{Ed}\right)$. New Jersey: Prentice-Hall Inc.

Gelles RJ. 1995. Contemporary families: $A$ Sociological View. London: SAGE Publications.

Hurlock EB. 1973. Adolescent Development $\left(4^{\text {th }} \mathrm{Ed}\right)$. New York: McGraw-Hill Book Company.

Khairuddin H. 1985. Sosiologi Keluarga. Yogyakarta: Nurcahaya.

Landis. 1989. Sociology: Concepts and Characteristics $\left(7^{\text {th }}\right.$ Ed). California: Wadsworth Inc.

Popov LK, Popov WD, Kevelin J. 1997. The Family Virtues Guide: Simple Ways to Bring Out the Best in Our Children and

\footnotetext{
* Korespondensi :

Telp : +62-2518628303

Email : herien_puspitawati@email.com
}

Ourselves. New York: The Penguin Group.

Puspitawati H, Hartoyo, Sarma M, Latifah M, Herawati T. 2009. Parent Satisfaction Survey of Basic Education Services Provided by Decentralised School System. Didanai oleh PRMAP-ADBBappenas kerjasama dengan LPPMIPB.

Schwartz MA, Scott BM. 1994. Marriages and Families: Diversity and Change. New Jersey: Prentice-Hall Inc.

UNESCO. 2005. Policy Framework For Improving The Quality Of Teaching and Learning.

Vosler NR. 1996. New Approaches to Family Practice Confronting Economic Stress. California: Sage Publications Inc. 